\title{
Effects of climate trends and drought events on urban tree growth in Santiago de Chile
}

\author{
Astrid Moser ${ }^{1}$, Enno Uhl'1, Thomas Rötzer ${ }^{1}$, Peter Biber ${ }^{1}$, Juan M. \\ Caldentey $^{2}$, and Hans Pretzsch ${ }^{1}$ \\ 'Technical University Munich, Weihenstephan, School of Life Sciences, Forest Growth and Yield Science. \\ Hans-Carl-von-Carlowitz-Platz 2, 85354 Freising, Germany \\ ${ }^{2}$ Universidad de Chile, Departamento de Silvicultura y Conservación de la Naturaleza. Av. Santa Rosa \\ 11315, Santiago, Chile
}

\begin{abstract}
A. Moser, E. Uhl, T. Rötzer, P. Biber, J.M. Caldentey, and H. Pretzsch. 2018. Effects of climate trends and drought events on urban tree growth in Santiago de Chile. Cien. Inv. Agr. 45(1): 35-50. Urban trees and the services they provide (e.g., evapotranspirational cooling, shading, recreation, carbon storage, air pollution filtering) can have major effects on the microclimate of a city, although the growth conditions are often inadequate to ensure tree vitality and growth, negatively affecting their beneficial effects. In a worldwide dendrochronological study on ten urban tree species in four climatic zones, the growth and impacts of common urban tree species were assessed. This paper focuses on the results for Robinia pseudoacacia $\mathrm{L}$. in the Mediterranean climate city of Santiago de Chile, highlighting the faster growth of the studied black locust trees since 1960 than its growth in the years before 1960. Furthermore, black locust displayed the best growth when situated closer to the city center than the city periphery and when in the northern and western parts of Santiago de Chile. The species characteristics of black locust also revealed an immediate negative growth reaction to drought events, followed by a rapid recovery, which was similarly influenced by the direction from and distance to the city center of the growing site. The results underline the overall worldwide findings on urban tree growth that indicate that a city climate with an extended growing season and increased temperatures can lead to improved growth of urban trees in the Mediterranean climatic zone. However, with increased growth, more rapid ageing and tree death might follow, leading to increased costs for new plantings and tree management.
\end{abstract}

Keywords: Bioindication, growth trends, resistance, Robinia pseudoacacia, tree ring analyses.

\section{Introduction}

Climate change affects the living conditions and plant growth (plant distribution, net primary productivity) worldwide (Cavin et al., 2013). Despite

Received May 02, 2017. Accepted February 13, 2018. Corresponding author: astrid.moser@1rz.tum.de numerous studies on the consequences of climate change on the worldwide climate and the well-being of humans (e.g., Costello et al., 2009; Jeppesen et al. 2009), the effects of a changed climate on the climatic conditions of cities in different climate zones are largely unknown. Particularly, the impacts of climate change on big cities are likely be much more pronounced because climate change is 
expected to amplify the urban heat island effect of cities (Coburn, 2009). Currently, megacities such as Tokyo experience urban heat islands up to $12{ }^{\circ} \mathrm{C}$ in summer (Tran et al., 2006). Weng et al. (2004) found a significant urban heat island for the industrial area of Indianapolis in the U.S., and Tran et al. (2006) described an average urban heat island for tropical cities in Asia from 5 to $8{ }^{\circ} \mathrm{C}$ in the dry season. Future climates with increased temperatures and reduced precipitation will most severely affect cities with a current subtropical or Mediterranean climate (IPCC, 2013; Mueller et al., 2005), leading to an increased urban heat island in city centers with increases in temperatures, particularly during the night (Tan et al., 2010). The changed climatic conditions will directly influence the living conditions of the urban populations and could be detrimental for the quality of life for humans and also all other biota (Santamouris et al., 2011). Santiago de Chile, Chile, is an example of a city that will suffer most from climate change and the urban heat island effect. Moreover, Santiago de Chile faces current problems, such as heavy air pollution (Artaxo et al., 1999) and desertification (Caldentei, pers. commun.), which further decrease the quality of life for city dwellers. Santiago, with the surrounding agglomeration including more than 7.5 million inhabitants, presents a unique growing climate for urban trees. Although the overall climate is characterized as Mediterranean with warm summers and mild winters, the coastal cordilleras to the west, the Andes Mountains to the east and a plain valley to the south create markedly varying conditions throughout the city (Arroyo and Martínez, 1988; Tofeili, 2013). This unique setting, the prevalent climate conditions and the environmental problems provide an unfavorable climate for the city inhabitants, which will be worsened by climate change.

The use of green infrastructure, such as urban trees and shrubs, is a commonly applied measure to buffer the negative aspects (urban heat island, air pollution) of living in large cities, such as Santiago. Urban trees provide evaporative cooling and shading, air pollution removal, wind and noise buffering, run-off mitigation and recreational services (Moser et al., 2015; Tyrväinen et al., 2005). The amelioration of the city climate by urban trees has been investigated in several studies in past years (Dimoudi and Nikolopoulou, 2003; Dobbs et al., 2014), which highlight the importance of trees for the current and the future climates of the city. Urban forests will have a key function in adapting cities to climate change.

Among the planted urban tree species in Santiago, Robinia pseudoacacia L. (black locust) is a frequently found species (Haig et al., 1946; Li et al., 2014). Despite the natural origin of $R$. pseudoacacia in continental and humid North America in high precipitation and high humidity forest stands, the tree is classified as a medium to very drought tolerant species, which is commonly found in urban regions because of its hardiness to typical urban conditions (Keresztesi, 1988; Roloff, 2013). Since the introduction to Europe, R. pseudoacacia has developed as a well growing species in dry and warm parts of south Europe (Vítková et al., 2017). Black locust is a lightdemanding, isohydric and ring-porous species, characterized by comparably hard wood and has mycorrhizal partnerships (Moser et al., 2016; Roloff, 2013). As Moser et al. (2015) demonstrated in their study on two common European urban tree species, including $R$. pseudoacacia, urban trees can have a substantial effect on the urban microclimate. An 80-year-old R. pseudoacacia tree can store up to $3,280 \mathrm{~kg}$ of carbon, shade an area up to $1,200 \mathrm{~m}^{2}$ and remove $13,644 \mathrm{kWh}$ of energy from the atmosphere for cooling. Albeit, urban areas are difficult sites for trees, affecting their vitality and the services they provide. Urban trees mostly suffer from water shortage, warmer temperatures, high nitrogen input, air pollution, and limited rooting and aboveground space, which affect the growth, resilience and mortality of urban trees (Akbari et al., 2001; Clark and Kjelgren, 1990; Fahey et al., 2013).

Several studies in past decades examined the effects of urban conditions on tree growth; for 
example, see Kjelgren and Clark (1992) and Moser et al. (2015). However, only the worldwide study of Pretzsch et al. (2017) investigates the effects of different urban microclimates on the growth of urban trees. In that study, a total of 1,383 urban trees were dendrochronologically sampled in ten metropolises worldwide, covering hemi- to boreal (Sapporo, Japan; Prince George, Canada), temperate (Paris, France; Munich and Berlin, Germany), Mediterranean (Cape Town, South Africa; Santiago de Chile, Chile), and subtropical (Hanoi, Vietnam; Houston, USA; Brisbane, Australia) climate conditions (Köppen, 1918; Köppen and Geiger, 1930-1939). The sampled trees of a defined species per city were selected from the city center to the suburban and rural areas and in all four primary directions from the city center. The following species were covered by the study: Abies sachalinensis Mast. (Sachalin fir), Picea glauca (Moench) Voss (white spruce), Tilia cordata Mill. (small-leaved lime), Aesculus hippocastanum L. (horse-chestnut), Platanus $x$ hispanica Münchh. (London plane), Robinia pseudoacacia L. (black locust), Quercus robur L. (English oak), Khaya senegalensis (Desr.) A. Juss. (African mahogany), Araucaria cunninghamii Aiton ex. D.Don) (hoop pine), and Quercus nigra L. (water oak). Dating back more than 100 years, the tree ring chronologies reflect the effect of global climate change and the urban heat island on urban tree growth worldwide.

The study showed an increased growth rate of urban trees since the 1960's (Pretzsch et al., 2017). Similar effects caused by climate change (e.g., increased temperatures, extension of the growing season, elevated atmospheric $\mathrm{CO}_{2}$ concentrations) have been analogously reported for forest trees and stands worldwide (Chmielewski and Rötzer, 2001; Churkina et al., 2010; Fang et al., 2014; IPCC, 2014; Pretzsch et al., 2014). On average, across all cities and across the entire time span, urban trees grew more rapidly than those in the rural surroundings. The urban heat island preempts the climate influence in general but is most pronounced in the boreal climate (Pretzsch et al., 2017). In almost all investigated cities, except those in a temperate climate, the negative effects of the urban environment (e.g., reduction of photosynthesis by biogenic volatile organic compounds (BVOCs), fine dust, drought stress) are overcompensated by its benefits, such as an elongated growing period or fertilization due to emissions (Chmielewski and Rötzer, 2001; Churkina et al., 2010; Moser et al., 2017; Pretzsch et al., 2017).

Research into the development of urban trees in Santiago is part of this global study on growth trends of urban trees in metropolises. Here, we explore in detail how the climate trends and events affected the growth of Robinia pseudoacacia in Santiago, a metropolitan city of the Mediterranean climatic zone (Köppen, 1918; Köppen and Geiger, 1930-1939), posing the following research questions:

1. What was the growth of R. pseudoacacia from past to present in the urban region of Santiago de Chile?

2. Are overall trends in the growth of $R$. pseudoacacia in Santiago de Chile similar to those found worldwide for urban trees?

3. Does the growth of $R$. pseudoacacia differ on sampling transects from sites in the city center to those in the north and south and east and west?

4. Does the growth behavior of R. pseudoacacia show temporal change?

5. Does growth differ in relation to the distance from the city center to rural sites?

\section{Materials and Methods}

\section{Climate of Santiago de Chile}

The climate of Santiago de Chile is characterized as Mediterranean with warm summer months and 
accordingly low precipitation rates from October to April. In winter, from May to September, the temperatures are mild with high amounts of precipitation. The mean temperature of Santiago is approximately $14{ }^{\circ} \mathrm{C}$, whereas the precipitation rate varies severely depending on the site (Dirección Meteorológica de Chile, 2013). The weather station closest to the city center, Quinta, recorded $320 \mathrm{~mm}$ of precipitation, whereas the weather station farthest from the city center located in the western direction, Pudahuel, recorded only 263 $\mathrm{mm}$ of precipitation. At the weather station in the east, Tobalaba, the highest rates of precipitation were measured $(340 \mathrm{~mm})$. These patterns might be influenced by the specific location of Santiago with the Andes Mountains in the east, the sea in the west and the coastal cordilleras running from north to south, resulting in great differences in altitude and humidity (Arroyo and Martínez, 1988; Tofeili, 2013).

To characterize the water supply for each year, we calculated the index of de Martonne (1926) $\mathrm{M}(\mathrm{M}=$ precipitation $(\mathrm{mm}) /$ (mean temperature $\left.{ }^{\circ} \mathrm{C}+10\right)$ ) on the basis of the precipitation (in $\mathrm{mm}$ ) and mean temperature (in ${ }^{\circ} \mathrm{C}$ ) in the entire year from 1982 to 2011 (Fig. 1). Clearly distinguishable are the drought years 2003, 1998 and 1990.

\section{Data Collection}

Throughout the city, 145 R. pseudoacacia trees were chosen for data collection. The trees were roughly selected along transects through the city from north to south and from east to west to include the geographic influences (altitude, humidity) of the city region on tree growth, such as the Andes Mountains, precordillera, Chilean Coastal Range, sea and flat areas (Fig. 2). Healthy looking, unpruned trees were selected that did not receive irrigation. The selected trees were chosen to be a representative sample of typical urban trees in Santiago, growing in street canyons, parks, public squares and housing areas. Trees growing at a distance up to $10 \mathrm{~km}$ from the city center were classified as urban, whereas all trees growing at a distance more than $10 \mathrm{~km}$ from the city center were sampled as rural. Moreover, trees growing in the northern quadrant were classified as trees growing in the northern cardinal direction, and uniform criteria were applied for the eastern, southern and western quadrants.

Before increment core collection, data on tree structure and the site conditions were recorded, including diameter at breast height $1.3 \mathrm{~m}(\mathrm{dbh})$, tree height (h), height to the crown base (cb), crown radius in four directions $(\mathrm{N}, \mathrm{E}, \mathrm{S}, \mathrm{W})$, tree

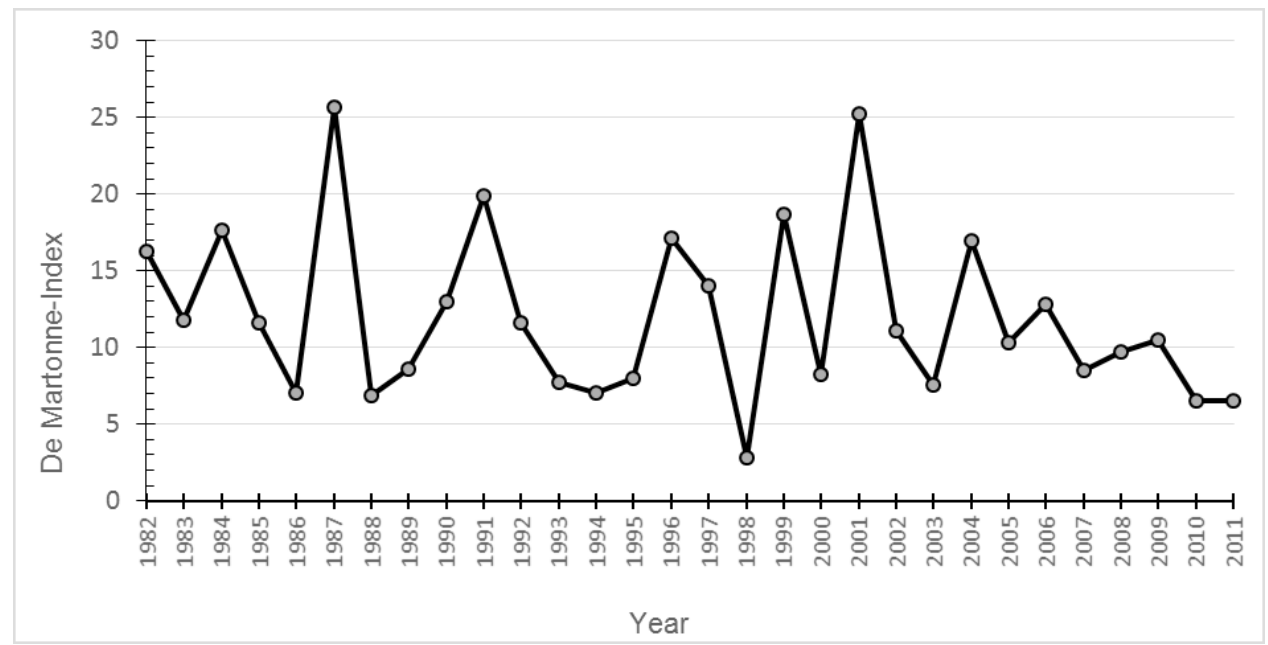

Figure 1. De Martonne-Index for Santiago de Chile from 1982 to 2011 per year. The drought years 2003, 1998 and 1986 are marked in the figure. 

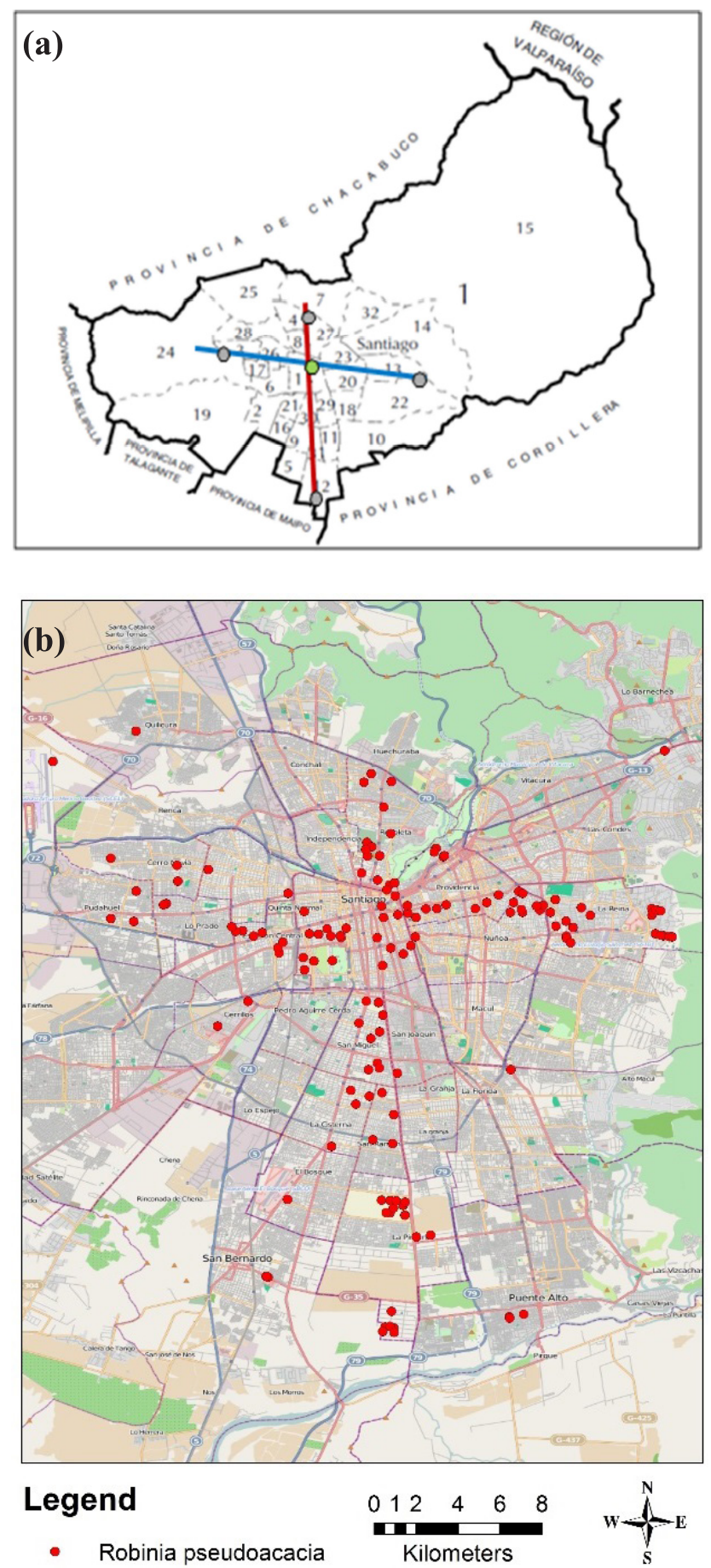

Figure 2. Santiago de Chile: (a) the transects through the city from north to south (red line) and east to west (blue line) and (b) the data points of recorded $R$. pseudoacacia trees. 
position (coordinates and altitude), site condition, tree vitality, and open surface area of the unpaved area around the tree in four directions. Then, increment core collection was conducted at each tree. Two cores opposite to one another were extracted at a height of $1.3 \mathrm{~m}$ in northern and western directions with a $5 \mathrm{~mm}$ increment corer (Haglöf Sweden AB; Långsele, Västernorrland, Sweden). Based on these recorded data, the crown radius cr (eq. 1), crown projection area cpa (eq. 2), crown volume cv (eq. 3) and open surface area OSA (eq. 4) were calculated.

$c r=\sqrt{\left(r_{\mathrm{N}}^{2}+r_{\mathrm{E}}^{2}+r_{\mathrm{S}}^{2}+\mathrm{r}_{\mathrm{W}}^{2}\right) / 4}$

where $r_{\mathrm{N}}$ is the widest measured crown extension in the northern direction,..., and $r_{w}$ is the widest crown extension in the western direction.

$$
\begin{aligned}
& \mathrm{CPA}=\mathrm{cr}^{2} * \pi \\
& \mathrm{cv}=\mathrm{CPA} \times \mathrm{cb}
\end{aligned}
$$

$$
\mathrm{OSA}=\sqrt{\left(1_{\mathrm{N}}^{2}+1_{\mathrm{E}}^{2}+1_{\mathrm{S}}^{2}+1_{\mathrm{W}}^{2}\right) / 4}
$$

where $1_{N}$ is the distance from the tree bole to the paved area in the northern direction,..., and $l_{w}$ is the distance from the tree bole to the paved area in the western direction.

\section{Core and Data Processing}

The cores were processed with a sledge microtome, and each core was soaked in distilled water for $15 \mathrm{~min}$ before slicing. The cores were then mounted in the microtome with regard to the grain direction. With constant movements along the sledge, wood was removed until the highest visibility of the cross-sectional area was observed consistently for every core. The annual tree-ring widths of the cores were then measured with a digital positioning table with a resolution of 1 $100 \mathrm{~mm}^{-1}$ (Rinntech e.K.; Heidelberg, Germany).
For cross dating of the time-series, the software package TSAP-Win (Rinntech e.K.; Heidelberg, Germany was used. All following analyses were conducted with the package dplR of R (Bunn et $a l ., 2015)$. The tree-ring series were detrended with a double detrending process, applying modified negative exponential curves and cubic smoothing splines (20 years rigidity, 50\% wavelength cutoff), further averaged with Tukey's biweight robust mean. The autocorrelation of every series was removed using autoregressive models (max. order of 3). All further analyses of climate-growth correlations were conducted with the resulting chronologies. From the chronologies, the age of the analyzed trees was derived. When the exact age of the tree was not clear (missing tree pith, among others), the age was back calculated based on the undetrended average growth rate of the last ten years and the dbh of the tree.

\section{Drought analysis}

Moreover, we analyzed the influence of drought years on tree growth using a Superposed Epoch Analysis (SEA) (Moser et al., 2016). SEA assesses the significance of events such as droughts on tree growth during drought and post-drought growth periods (Bunn et al., 2015). Deviations from the mean RWI were averaged for the drought year and 5 yrs after the drought year (post-drought years). The significance of the departures was detected with randomly selected sets of 6 yrs from 1,000 bootstrapped sets.

\section{Trend analysis (long-term trends)}

Using the R package lme4, two linear mixed models of the following forms 5 and 6 were developed to assess the influence of the time of age, growth (before 1960-since 1960) and urbanity (urbanrural) on the annual basal area (response variable) derived by increment cores. To differentiate between the two growth-trend relevant periods, we introduced the dummy variable recent, 1 for 
each observation later than 1959 and 0 otherwise, which is in accordance with growth trends since approximately the 1960s that have been identified for forest trees.

$\ln \left(b a_{i j}\right)=\mathrm{a}_{0}+\mathrm{a}_{l} \times$ time $_{i j}+\left(b_{0}+b_{l} \times\right.$ time $\left._{i j}\right) \times \log \left(a g e_{i j}\right)+c_{i j}+\varepsilon_{i j}$,

$\ln \left(b a_{i j}\right)=\mathrm{a}_{0}+\mathrm{a}_{l} \times u r b_{i j}+\left(b_{0}+b_{l} \times u r b_{i j}\right) \times \log \left(a g e_{i j}\right)+c_{i j}+\varepsilon_{i j}$,

where the basal area is the response variable for the $\mathrm{jth}$ of $\mathrm{n}_{\mathrm{i}}$ observations in the ith of $\mathrm{M}$ groups or clusters, and $a_{1}, \ldots, a_{n}$ and $b_{1}, \ldots, b_{n}$ are the fixed effects with the " $a$ " parameters components of the intercept and the " $b$ " parameters components of the slope. When $a_{1}$ in eq. 5 differed significantly from 0 , the age-basal area relationship before 1960 had a different intercept than that since 1960. In eq. 6 , the different intercept would indicate that the intercept of urban trees was not the same as that for rural trees. The parameter $b_{1}$ in both equations has an analogous meaning to that of the slope. The "c" parameters are random effects, which are assumed to have a normal distribution. These random effects cover statistical dependencies, which are due to the nested data structure. The errors $\varepsilon_{i j}$ are assumed to have an i.i.d. distribution.

\section{Results}

In Table 1, the mean, minimum and maximum characteristics of all analyzed $R$. pseudoacacia trees are summarized. The dbh minimum of trees was $19.8 \mathrm{~cm}$, and the maximum dbh was $56.1 \mathrm{~cm}$, with an average dbh of $41.4 \mathrm{~cm}$, which equalized to a mean age of $49 \mathrm{yrs}$. The increment coring occurred in trees from the city center to the outer margins of the city area with a maximum distance to the city center of $20.3 \mathrm{~km}$. The average radius increment per year for all cored trees was $4.39 \mathrm{~mm}$.
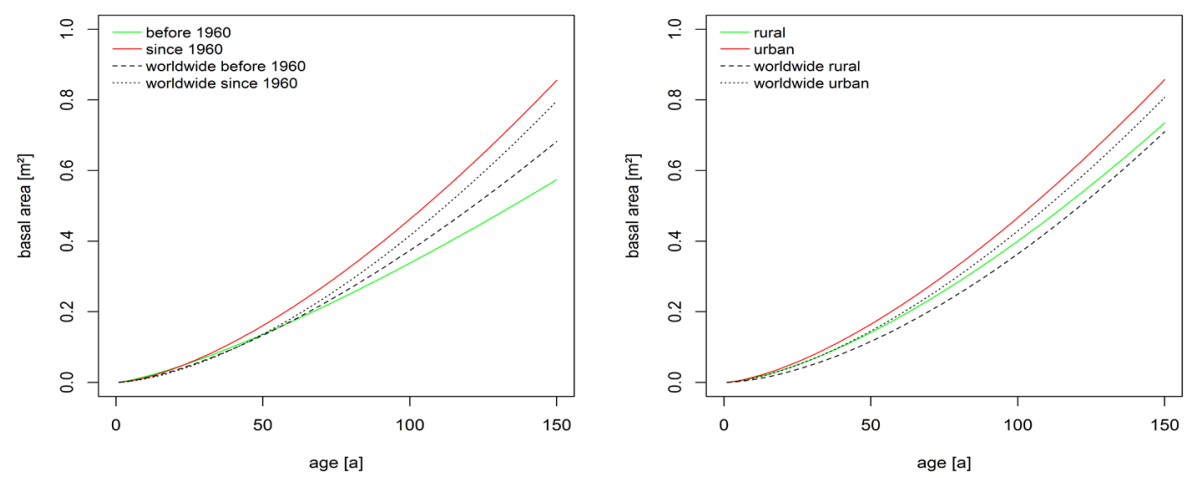

Figure 3. The growth in size in terms of basal area growth of $R$. pseudoacacia in Santiago de Chile and for worldwide urban trees (Pretzsch et al., 2017) for (a) the period before 1960 compared with the period since 1960 and (b) urban trees compared with rural growing trees.

Table 1. Minimum, average and maximum dbh, radius growth (RG), tree height, age, crown base, crown length, CPA, crown volume and distance to city center of the analyzed R. pseudoacacia trees in Santiago de Chile

\begin{tabular}{lccccccccc}
\hline & Dbh $[\mathrm{cm}]$ & $\begin{array}{c}\text { RG } \\
{\left[\mathrm{mm} \mathrm{a}^{-1}\right]}\end{array}$ & $\begin{array}{c}\text { Tree height } \\
{[\mathrm{m}]}\end{array}$ & Age $[\mathrm{a}]$ & $\begin{array}{c}\text { Crown } \\
\text { base }[\mathrm{m}]\end{array}$ & $\begin{array}{c}\text { Crown } \\
\text { length }[\mathrm{m}]\end{array}$ & $\begin{array}{c}\text { CPA } \\
{\left[\mathrm{m}^{2}\right]}\end{array}$ & $\begin{array}{c}\text { Crown } \\
\text { volume }\left[\mathrm{m}^{3}\right]\end{array}$ & $\begin{array}{c}\text { Distance to city } \\
\text { center }[\mathrm{km}]\end{array}$ \\
\hline Min & 19.8 & 0.41 & 4.8 & 11.0 & 1.7 & 2.4 & 6.0 & 0.5 & 0.8 \\
Avg & 41.4 & 4.39 & 15.3 & 49.3 & 2.7 & 12.6 & 58.4 & 23.4 & 7.7 \\
Max & 56.1 & 27.23 & 31.5 & 105.0 & 6.3 & 28.6 & 485.1 & 133.0 & 20.3 \\
\hline
\end{tabular}




\section{Long-term growth trends}

The analysis of the past growth of $R$. pseudoacacia in Santiago (question 1 and 2) revealed faster growth from 1960 to 2010 (Fig. 3a, red line) than that in the period before 1960 (green line). The growth of $R$. pseudoacacia since 1960 was even greater than the average growth of all analyzed trees and cities in the worldwide study (black lines). The growth of trees in Santiago was analyzed further regarding their distance to the city center (Fig. 3b). When growing close to the city center, the site was categorized as urban, and when a tree was growing at a farther distance to the city center in the suburbs of Santiago, the site was assessed as rural. The results highlighted better tree growth in the city center region (red line) than that of trees in the more outside region (rural, green line). Again, the growth of $R$. pseudoacacia in Santiago was compared with the average worldwide values of urban trees (question 3), with similar results to those shown in Figure 3b. The growth values for trees in Santiago were slightly greater than those found for all cities combined (black lines).
The results of the linear model shown in Figure 3a illustrate that age had a significant positive effect on tree growth, in addition to the time of growth related to the age (Table 2a). However, the time of growth had a negative effect on growth, which implied better growth of $R$. pseudoacacia in the period since 1960 than that in the period before 1960 (question 4). In Table 2b, the results of the linear mixed model are summarized for the effect of urbanity on the growth of R. pseudoacacia (Fig. $3 b$, question 5). Similar to the results of the model displayed in Table 2a, age had a significant positive effect on growth. The grade of urbanity (distance from the city center) had a positive relationship with growth; however, the effect on growth was not significant. Nevertheless, Figure 4 highlights a slight difference in the growth between urban and more rural trees.

\section{Short-term growth events}

The derived growth chronology for all sampled $R$. pseudoacacia trees in Santiago is shown in Figure 4 with the undetrended radius growth

Table 2a. Results of the linear mixed model on the annual basal area increment $\left(\mathrm{mm}^{2} \mathrm{yr}^{-1}\right)$ of all analyzed trees (response variable) with the individual tree code as random effect and the fixed effects $\log$ (age), time of growth (period before 1960 and period since 1960) and their interaction

\begin{tabular}{|c|c|c|c|}
\hline Parameter & Fixed effect & Value $\pm \mathrm{SE}$ & $\mathrm{p}$ \\
\hline $\mathrm{a}$ & Intercept & $-7.11 \pm 0.10$ & $<0.001$ \\
\hline $\log \left(a g e_{i . j}\right)$ & Log (age) & $1.31 \pm 0.03$ & $<0.001$ \\
\hline time $_{i \mathrm{ij}}$ & Time of growth & $-0.66 \pm 0.09$ & $<0.001$ \\
\hline$b \times$ time $_{i j} \times \log \left(a g e_{i j}\right)$ & Log (age) $\times$ Time of growth & $0.21 \pm 0.03$ & $<0.001$ \\
\hline Random effect $d_{i j}$ & & 0.30 & - \\
\hline$\varepsilon$ & & 0.25 & - \\
\hline
\end{tabular}

Levels of Time of growth: 2 (Before 1960, $\mathrm{n}=25$ and Since 1960, $\mathrm{n}=130$ ).

Table 2b. Results of the linear mixed model on the annual basal area increment $\left(\mathrm{mm}^{2} \mathrm{yr}^{-1}\right)$ of all analyzed trees (response variable) with the individual tree code as random effect and the fixed effects $\log$ (age), the grade of urbanity (urban and rural) and their interaction.

\begin{tabular}{lccc}
\hline Parameter & Fixed effect & Value $\pm \mathrm{SE}$ & $p$ \\
\hline $\mathrm{a}$ & Intercept & $-7.82 \pm 0.11$ & $<0.001$ \\
$\log \left(a g e_{i j}\right)$ & Log (age) & $1.50 \pm 0.01$ & $<0.001$ \\
$\operatorname{urb}_{\mathrm{ij}}$ & Urbanity & $0.15 \pm 0.13$ & 0.24 \\
$b \times \mathrm{urb}_{i j} \times \log \left(a g e_{i j}\right)$ & Log (age) $\mathrm{x}$ Urbanity & $0.001 \pm 0.02$ & 0.95 \\
$\operatorname{Random~effect~} d_{i j}$ & & 0.29 & - \\
$\varepsilon$ & & 0.25 & - \\
\hline
\end{tabular}

Levels of Urbanity: 2 (Urban, $n=98$ and Rural, $n=30$ ). 
values (Fig. 4a), the detrended values (Fig. 4b) and the basal area increments (Fig. 4c) and dates back from 2011, the year of the coring, to 1934. The chronologies display the long-term growth trend of the cored trees and years with positive and negative deviations from the mean growth. Extraordinarily good growth occurred in 1999, 1997, 1948 and 1937, whereas severe reductions in growth occurred in 1998, 1936 and 1934. Figure $4 \mathrm{c}$ shows the basal area increment, highlighting the accumulated growth over time.

In the next step, the growth of $R$. pseudoacacia in Santiago was analyzed in relation to the stand direction and site. Because all cored trees were chosen in the four cardinal directions, the growth in the central area of Santiago and in northern, eastern, southern and western directions was investigated in detail. Figure 5 presents the actual radius growth rates, the indexed growth values and the basal area increments of $R$. pseudoacacia divided in these five categories. Particularly in Figure 5a and c, a difference in the growth of the five categories is observed, and the growth in northern and western directions was markedly better than that in the other directions from the city center.

\section{Trends in relation to the growing site}

To investigate the reaction patterns of $R$. pseudoacacia to drought events, three exceptionally dry years (2003, 1998 and 1986) recorded for Santiago were used as input variables for a superposed epoch analysis SEA. Figure 6a reveals that $R$. pseudoacacia had a significant growth decline during those drought years (dark grey bar at epoch
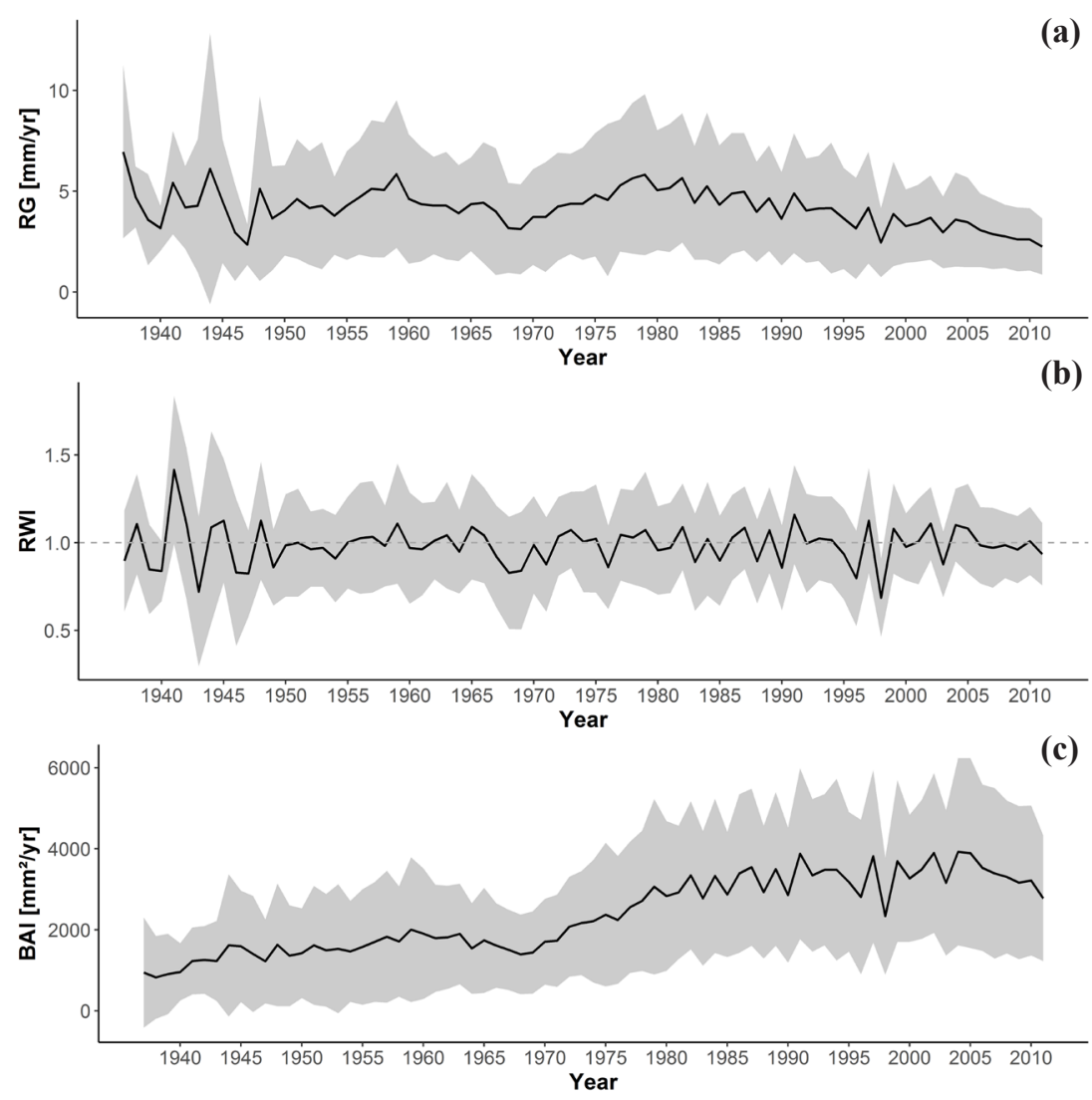

Figure 4. Radius growth (a), indexed growth values (b) and basal area increments (c) of all sampled $R$. pseudoacacia trees in Santiago de Chile. 

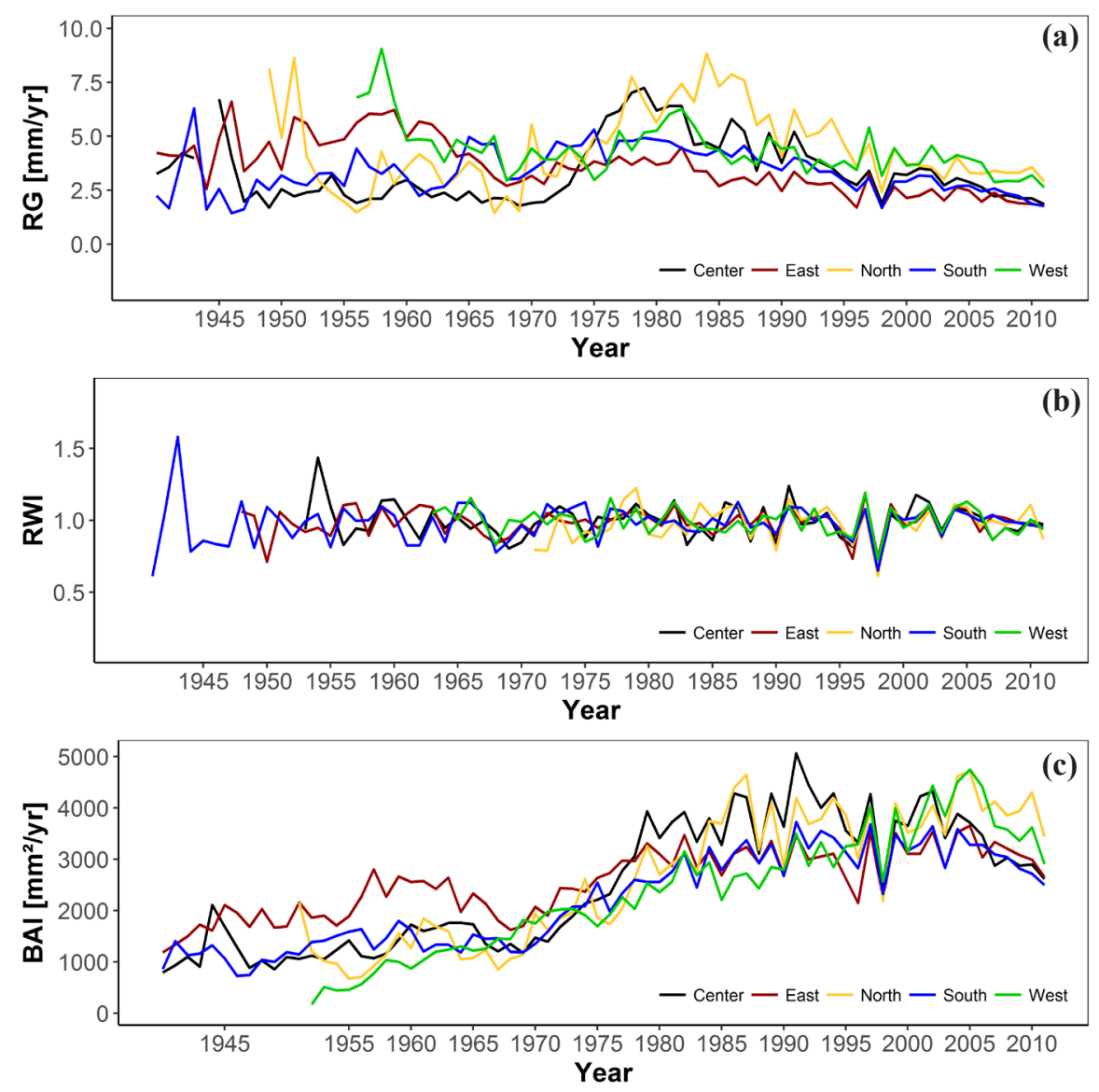

Figure 5. Radius growth (a), indexed growth values (b) and basal area increments (c) of $R$. pseudoacacia trees sampled in the city center and in eastern, northern, southern and western directions in Santiago de Chile.

$0)$. Before the analyzed drought episodes (-5 to -1), R. pseudoacacia displayed both positive and negative growth rates. After the drought events, $R$. pseudoacacia had remarkably high recovery (epoch 1), followed by a year with a small negative growth trend. However, the reaction to drought differed among the site categories center, north, east, south and west (Fig. 6b). In all directions, a reduction in growth was found for the drought years, which was significant for the directions east, south and west. The least decrease in growth was found for the center and the northern direction trees. For the first year after the drought events (1), a recovery was observed similar to the overall reaction. The recovery was significantly positive in northern and eastern directions, although the recovery was not significant for center, south and west directions. For the growth of $R$. pseudoacacia in Santiago classified in urban and rural growing sites, a similar drought response analysis was conducted (Fig. 6c). The reduction in growth observed for the overall growth related to the sampled directions was also found, although the decrease in growth was less severe for the trees at the urban sites compared with those at the more rural sites. The recovery in year 1 after the drought was also higher for the trees at the urban sites than at the rural ones.

\section{Discussion}

Growth of R. pseudoacacia in Santiago de Chile

The general growth of $R$. pseudoacacia in the urban region of Santiago was $4.4 \mathrm{~mm}$ on average 

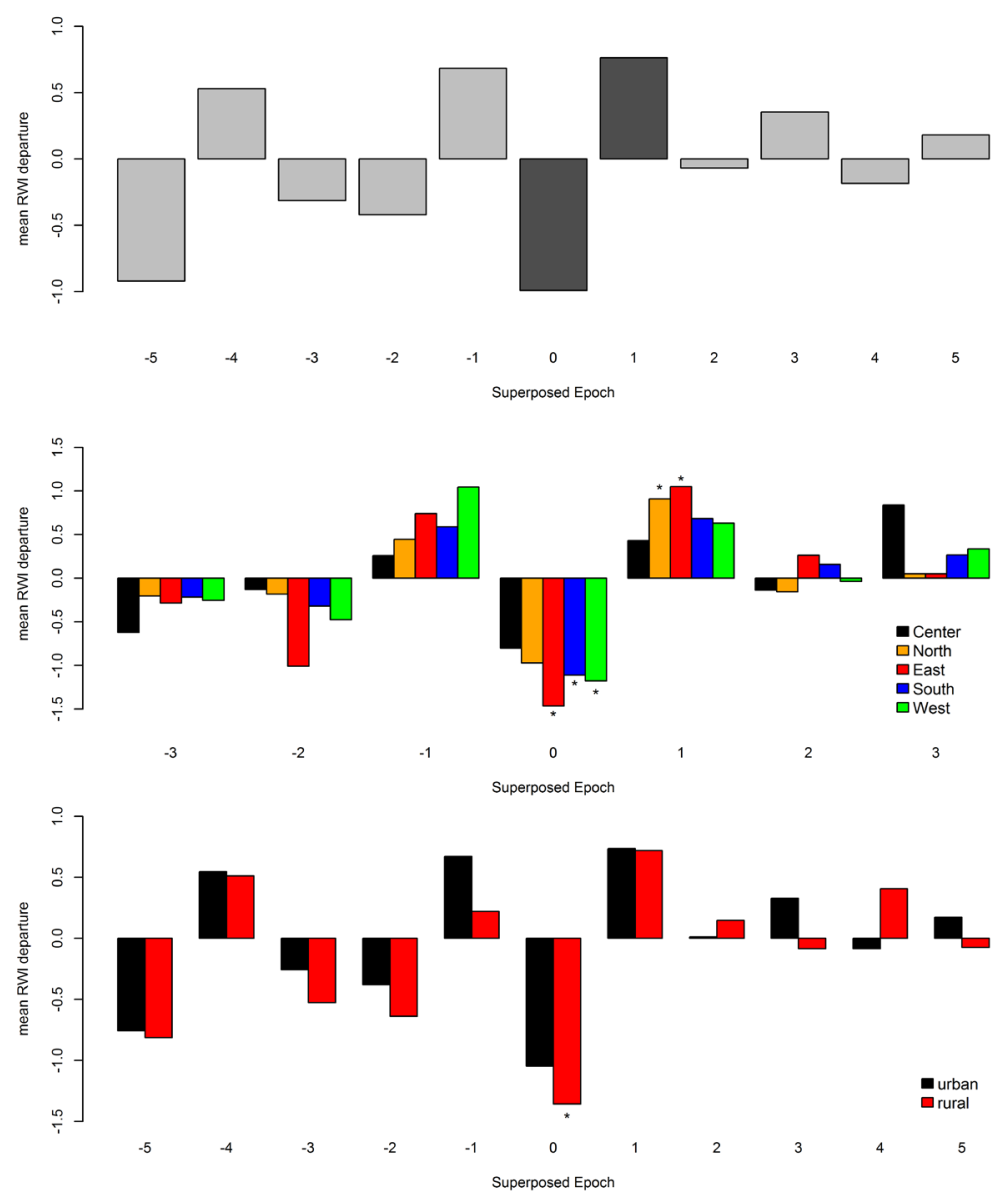

Figure 6. Superposed epoch analysis on the influence of drought periods (2003, 1998, and 1986) on the growth of $R$. pseudoacacia in Santiago de Chile (a) overall, (b) in the central area of Santiago de Chile and in the four cardinal directions (three years before and after the analyzed growth years are displayed because of the small sample size for some directions), and (c) in the urban and rural regions of Santiago de Chile. Significant departures from the mean at $\mathrm{p}<0.05$ are marked by *.

and was notably high in comparison with growth rates in other urban regions. Compared with the growth of 3.9 and $4.0 \mathrm{~mm}$ Moser et al. (2016) found for this species in two German cities, $R$. pseudoacacia performed under a warm climate significantly better than what could be expected from the natural range of $R$. pseudoacacia. Because this species occurs naturally at sites with very high precipitation rates (Keresztesi, 1988) and has sensitive reactions to drought events (Moser et al., 2016), increased growth at sites with more precipitation would be the expectation. A possible explanation for the good growth in Santiago under a dry climate might be the high temperatures.
Long-term Growth Trends of R. pseudoacacia

Urban trees are pivotal for many ecosystem services (e.g., provisioning, regulating, cultural, and supporting services) in cities. Any responses to global climate change and the urban heat island effect would affect human living, planning, and engineering in the complex socio-ecological systems that are modern cities. This study found that the growth of $R$. pseudoacacia in Santiago displayed a clear trend of faster growth since the 1960's than that in the time before 1960. These results are consistent with the worldwide trends for urban trees found by Pretzsch et al. (2017). 
Recent findings concerning growth trends in forests worldwide raise the question of how urban trees and forests will respond to changing environmental conditions. The worldwide study covered boreal, temperate, Mediterranean, and subtropical climate conditions and revealed that across all sampled climate zones, urban tree growth has significantly increased during the last decades (Pretzsch et al., 2017), counteracting the negative effects of the city climate, such as low water availability and the urban heat island effect. The most likely explanation for this effect are related to global climate change, including increases in temperatures (IPCC, 2014) and $\mathrm{CO}_{2}$ concentrations (Churkina et al., 2010) and prolonged growing seasons (Chmielewski and Rötzer, 2001). Thereby, on average, trees in the city centers grow significantly more rapidly than their conspecifics in the peripheral zones. The increase in growth and size in recent decades indicates increased carbon sequestration, accelerated spatial above- and belowground expansion, and earlier provisioning of many ecosystem services. However, these changes also indicate more rapid aging, possibly requiring earlier replanting. To sustain green urban infrastructure, planning and management should adapt to these changed dynamics.

\section{Short-term Growth Trends of R. pseudoacacia}

Urban tree growth is affected by several factors, which can inhibit or increase tree growth. As this study illustrated, increases in temperatures and in $\mathrm{CO}_{2}$ and nutrient levels can accelerate tree growth in cities (Chmielewski and Rötzer, 2001; Churkina et al., 2010; IPCC, 2014; Pretzsch et al., 2017). However, urban sites are mostly characterized by factors negatively influencing tree growth, e.g., small planting pits obtaining less water input, small rooting space and reduced aeration, light competition by buildings and vandalism (Morgenroth and Buchan, 2009; Moser et al., 2016). As the results for $R$. pseudoacacia in Santiago demonstrate, the growth of urban trees can also vary depending on their growth site within a city. Although the distance to the city center had an effect on the growth of $R$. pseudoacacia, the direction of the growing site was also significant for growth. Thus, the trees in northern and western directions had markedly better growth than that of the trees in the southern direction. These patterns might be influenced by the different meteorological conditions among the different settings and altitudes found in Santiago. Whereas in the western direction the influence of the sea is more pronounced with higher humidity, the eastern direction is close to the Andes Mountains with higher precipitation and lower temperatures. In northern direction, the coastal cordilleras result a higher altitude than that in the southern region of Santiago (Arroyo and Martínez, 1988; Tofeili, 2013). The colder and moister climatic conditions in the western and northern regions of the city of Santiago are more similar to those of the natural area of origin of $R$. pseudoacacia and therefore might explain the patterns of better growth than those of the dryer and warmer conditions in the more southern and eastern directions.

\section{Influence of Drought Events on the Growth of $\mathrm{R}$. pseudoacacia}

Because of the natural origin in the high precipitation and high humidity forest stands in North America, $R$. pseudoacacia is characterized as a less drought tolerant species. Although since the introduction to Europe, R. pseudoacacia has developed as a well growing species in dry and warm parts of south Europe and as a suitable species for urban sites (Roloff, 2013). Under those climatic conditions, $R$. pseudoacacia was notably less sensitive to dry sites and grew well particularly after drought events (Moser et al., 2016). The isohydric water conservation strategy of $R$. pseudoacacia can explain this behavior. During a drought event, $R$. pseudoacacia closes stomata quickly, which induces a low stomatal conductivity (Klein, 2014). Therefore, this species reduces the amount of water loss, although the 
risk of carbon starvation increases because of less photosynthesis. With this strategy, R. pseudoacacia can easily resist short drought periods and then quickly recover because of the preservation of water (Klein, 2014; Moser et al., 2016), which is consistent with the results of the drought analysis SEA: During the drought events, the growth of $R$. pseudoacacia was significantly reduced because of reduced photosynthesis. However, in the years following a drought event, $R$. pseudoacacia recovered immediately and responded with positive growth again. This pattern was observed throughout the city in all directions, although the severity of the growth reduction during the drought, and the magnitude of recovery after, was related to the growing site. The trees in the eastern direction displayed the highest growth reductions compared with all other directions but also had the best recovery. Notably, the trees in the city center had minor growth reductions but low growth rates after a drought event, although the growth was slightly better in the year after a drought event than that of the rural trees.

Overall, as this study demonstrated, the performance of urban trees regarding their growth and services is markedly influenced by the climate, urbanity and geographical location of the site. Because of climate change with increased temperatures, increased $\mathrm{CO}_{2}$ levels and a longer growing period, changes occur in urban tree growth. These patterns are found worldwide in all climate zones, although varying in extent, as illustrated by Pretzsch et al. (2017). Cities with a
Mediterranean climate, such as Santiago de Chile, will be most severely affected by climate change because their current climate conditions and urban heat island effect will be intensified. Robinia pseudoacacia trees in Santiago performed better under those changed urban climate conditions than trees in more rural sites. However, whether this trend would continue under more harsh growing conditions is doubtful. To date, the positive effects of the urban environment remain predominant over the negative growing conditions prevalent in cities, such as small planting pits and reduced water availability. Even under current conditions, the accelerated growth might lead to increased ageing and tree death, decreasing the services and benefits that urban trees, particularly the older trees, provide, which might be detrimental for the living conditions in cities such as Santiago. Further studies on the effects of climate change on the growth and services of urban trees are required to ensure low-cost, healthy and beneficial urban green for a comfortable climate in cities.

\section{Acknowledgements}

Thanks to the AUDI Environmental Foundation for funding this study (project 5101954: "Reaktionskinetik von Bäumen unter Klimaveränderungen" - "Reaction kinetics of trees under climate change"). All contributors thank the municipal authority of Santiago de Chile, Chile, for supporting the search for the trees and the permission to measure and core the trees.

\section{Resumen}

A. Moser, E. Uhl, T. Rötzer, P. Biber, J.M. Caldentey, y H. Pretzsch. 2018. Efecto de las tendencias climaticas y de eventos de sequía en el crecimiento de árboles urbanos en Santiago de Chile. Cien. Inv. Agr. 45(1): 35-50. Los árboles urbanos y los servicios que proporcionan (ej.: enfriamiento por evapotranspiración, sombra, recreación, acumulación de carbono y purificación del aire) pueden tener impactos significativos en el microclima de una ciudad. Ello, a pesar que las condiciones en las urbes, suelen ser inadecuadas para asegurar la vitalidad y el crecimiento de los árboles, disminuyendo sus efectos benéficos. En un estudio dendrocronológico mundial, se evaluó el impacto de las tendencias climáticas en el crecimiento 
de diez especies urbanas, en cuatro condiciones climáticas. Los resultados obtenidos al estudiar ejemplares de Robinia pseudoacacia L. plantados en Santiago de Chile muestran un mayor crecimiento de los árboles desde el año 1960, comparado con años anteriores, con mayores incrementos desde la periferia hacia el centro de la ciudad, así como en las zonas norte y oeste de ésta. En repuesta a sequías, la especie presenta disminuciones inmediatas en el crecimiento de los árboles, seguidas de una rápida recuperación, dependiendo de su ubicación geográfica y del distanciamiento al centro de la ciudad. Los resultados evidencian la tendencia global de que el clima urbano, con una estación de crecimiento más larga y temperaturas más altas, puede causar que los árboles urbanos, en la zona climática mediterránea, crezcan más rápido. Este crecimiento mayor podría ser seguido por un envejecimiento más rápido y la muerte de los árboles, provocando aumentos en los costos de reforestación y manejo de los árboles.

Palabras clave: Crecimiento de árboles urbanos, reacciones a la sequía, Robinia pseudoacacia, tendencias de crecimiento.

\section{References}

Akbari, H., M. Pomerantz, and H. Taha. 2001. Cool surfaces and shade trees to reduce energy use and improve air quality in urban areas. Sol Energy 70:295-310.

Arroyo, M.T.K., and J.A. Martínez. 1988. Effects of aridity on plant diversity in the northern Chilean Andes. Results of a natural experiment. Ann. Mo. Bot. Gard. 75:55-78.

Artaxo, P., P. Oyola, and R. Martinez. 1999. Aerosol composition and source apportionment in Santiago de Chile. Nucl. Instr. Meth. Phys. Res B 150:409-416.

Bunn, A., M. Korpela, F. Biondi, F. Campelo, P. Mérian, F. Qeadan, C. Zang, A. Buras, J. Cecile, M. Mudelsee, and M. Schulz. 2015. Package 'dplR'. Dendrochronology Program Library in $\mathrm{R}$, Version 1.6.3 ed.

Cavin, L., E.P. Mountford, G.F. Peterken, and A.S. Jump. 2013. Extreme drought alters competitive dominance within and between tree species in a mixed forest stand. Funct Ecol 27:1424-1435.

Chmielewski, F.M., and T. Rötzer. 2001. Response of tree phenology to climate change across Europe. Agric For Meteorol 108:101-112.

Churkina, G., S. Zaehle, J. Hughes, N. Viovy, Y. Chen, M. Jung, B.W. Heumann, N. Ramankutty, M. Heimann, and C. Jones. 2010. Interactions between nitrogen deposition, land cover conver- sion, and climate change determine the contemporary carbon balance of Europe. Biogeosciences 7:2749-2764.

Clark, J.R., and R. Kjelgren. 1990. Water as a limiting factor in the developement of urban trees. J Arboric 16:203-208.

Coburn, J. 2009. Cities, Climate Change and Urban Heat Island Mitigation: Localising Global Environmental Science. Urban Studies 46:413-427.

Costello, A., M. Abbas, A. Allen, S. Ball, S. Bell, R. Bellamy, S. Friel, N. Groce, A. Johnson, M. Kett, M. Lee, C. Levy, M. Maslin, D. McCoy, B. McGuire, H. Montgomery, D. Napier, C. Pagel, J. Patel, J. Antonio, P. de Oliveira, N. Redclift, H. Rees, D. Rogger, J. Scott, J. Stephenson, J. Twigg, J. Wol, and C. Patterson. 2009. Managing the health effects of climate change. Lancet 373:1693-1733

de Martonne, E. 1926. Une novelle fonction climatologique: L'indice d'aridité. La Météorologie 21:449-458.

Dimoudi, A., and M. Nikolopoulou. 2003. Vegetation in the urban environment: microclimatic analysis and benefits. Energy Build 35:69-76.

Dirección Meteorológica de Chile. 2013. Climatologia. Datos y Productos Climatológicos, www. meteochile.gob.cl/climatologia.php.

Dobbs, C., D. Kendal, AND C.R. Nitschke. 2014. Multiple ecosystem services and disservices of the urban forest establishing their connections 
with landscape structure and sociodemographics. Ecol Indic 43:44-55.

Fahey, R.T., M.B. Bialecki, and D.R. Carter. 2013. Tree Growth and Resilience to Extreme Drought Across an Urban Land-use Gradient. Arboric Urban For 39:279-285.

Fang, J., T. Kato, Z. Guo, Y. Yang, H. Hu, H. Shen, X. Zhao, A.W. Kisimoto-Mo, Y. Tang, and R.A. Houghton. 2014. Evidence for environmentally enhanced forest growth. PNAS 111:9527-9532.

Haig, I.T., L.V. Teesdale, P.A. Briegleb, B.H. Payne, and M.H. Haertel. 1946. Forest Resources of Chile as a Basis for Industrial Expansion. United States Forest Service

IPCC, 2013. Climate Change 2013: The Physical Science Basis. IPCC Working Group I Contribution to AR5.

IPCC, 2014. Synthesis Report, International Panel on Climate Change. Cambridge Univ Press.

Jeppesen, E., B. Kronvang, M. Meerhoff, M. Søndergaard, K.M. Hansen, H.E. Andersen, T.L. Lauridsen, L. Liboriussen, M. Beklioglu, A. Özen, and J.E. Olesen. 2009. Climate Change Effects on Runoff, Catchment Phosphorus Loading and Lake Ecological State, and Potential Adaptations. J. Environ. Qual. 38:1930-1941.

Keresztesi, B. 1988. The black locust. Akadémiai Kiadó, Budapest, Hungary

Kjelgren, R.K., and J.R. Clark. 1992. Microclimates and Tree Growth in Tree Urban Spaces. J Environ Hortic 10:139-145.

Klein, T. 2014. The variability of stomatal sensitivity to leaf water potential across tree species indicates a continuum between isohydric and anisohydric behaviours. Funct Ecol 28:1313-1320.

Köppen, W. 1918. Klassification der Klimate nach Temperatur, Niederschlag and Jahreslauf, Petermanns Geog. Mitt.

Köppen, W., and G. Geiger. 1930-1939. Handbuch der Klimatologie. Gebrüder Borntraeger, Berlin

Li, H., G. Xu, K. Guo, and S. Du. 2014. Mapping the Global Potential Geographical Distribution of Black Locust (Robinia Pseudoacacia L.) Using Herbarium Data and a Maximum Entropy Model. Forests 5:2773-2792.
Morgenroth, J., and G.D. Buchan. 2009. Soil moisture and aeration beneath pervious and impervious pavements. Arboric Urban For 35:135-141.

Moser, A., T. Rötzer, S. Pauleit, and H. Pretzsch. 2015. Structure and ecosystem services of small-leaved lime (Tilia cordata Mill.) and black locust (Robinia pseudoacacia L.) in urban environments. Urban For Urban Greening 14:1110-1121.

Moser, A., T. Rötzer, S. Pauleit, and H. Pretzsch. 2016. The urban environment can modify drought stress of small-leaved lime (Tilia cordata Mill.) and black locust (Robinia pseudoacacia L.). Forests 7:71.

Moser, A., E. Uhl, T. Rötzer, P. Biber, J. Dahlhausen, B. Lefer, and H. Pretzsch. 2017. Effects of Climate and the Urban Heat Island Effect on Urban Tree Growth in Houston. Open Journal of Forestry 7:428-445.

Mueller, R.C., C.M. Scudder, M.E. Porter, I.R.T. Trotter, C.A. Gehring, and T.G. Whitham. 2005. Differential tree mortality in response to severe drought: evidence for long-term vegetation shifts. J Ecol 93:1085-1093.

Pretzsch, H., P. Biber, G. Schütze, E. Uhl, and T. Rötzer. 2014. Forest stand growth dynamics in Central Europe have accelerated since 1870. Nat. Commun 5 (suppl. 1):4967.

Pretzsch, H., P. Biber, E. Uhl, J. Dahlhausen, G. Schütze, D. Perkins, T. Rötzer, J. Caldentey, T. Koike, T. van Con, B. du Toit, K. Foster, and B. Lefer. 2017. Climate change accelerates growth of urban trees in metropolises worldwide. Scientific Reports 7:1-10.

Roloff, A. 2013. Bäume in der Stadt. Ulmer, Stuttgart.

Santamouris, M., A. Synnefa, and T. Karlessi. 2011. Using advanced cool materials in the urban built environment to mitigate heat islands and improve thermal comfort conditions. Sol Energy 85:3085-3102.

Tan, J., Y. Zheng, X. Tang, C. Guo, L. Li, G. Song, X. Zhen, D. Yuan, A.J. Kalkstein, F. Li, and H. Chen. 2010. The urban heat island and its impact on heat waves and human health in Shanghai. Int J Biometeor 54:75-84.

Tofeili, C. 2013. Die Zuwachsdynamik von Robinia pseudoacacia L. entlang eines Stadtklimagradi- 
enten in der südamerikanischen Metropole Santiago de Chile, Chair of Forest Growth and Yield Science.

Tran, H., D. Uchihama, S. Ochi, and Y. Yasuoka. 2006. Assessment with satellite data of the urban heat island effects in Asian mega cities. International Journal of Applied Earth Observation and Geoinformation 8:34-48.

Tyrväinen, L., S. Pauleit, K. Seeland, and S. Vries. 2005. Benefits and Uses of Urban Forests and Trees, in: Konijnendijk, C., Nilsson, K., Randrup, T., Schipperijn, J. (Eds.), Urban Forests and Trees: A Reference Book. Springer Berlin Heidelberg, Berlin, Heidelberg, pp. 81-114.

Vítková, M., J. Müllerová, J. Sádlo, J. Pergl, and P. Pyšek. 2017. Black locust (Robinia pseudoacacia) beloved and despised: A story of an invasive tree in Central Europe. Forest Ecology and Management 384:287-302.

Weng, Q., D. Lu, and J. Schubring. 2004. Estimation of land surface temperature-vegetation abundance relationship for urban heat island studies. Remote Sensing of Environment 89:467-483. 